\title{
PEMBINAAN DAN PEMBIMBINGAN KEGIATAN LITERASI DASAR DALAM PEMBELAJAAN DI RUMAH SELAMA PANDEMI COVID-19 PADA ANAK-ANAK BANJAR DINAS TEMUKUS, DESA BESAKIH
}

\author{
I Nengah Sueca'), N. W. S. Darmayanti²) \\ 1)Program Studi Pendidikan Bahasa dan Sastra IndonesiaSTKIP Suar Bangli, Bangli, Bali, Indonesia \\ 2) Program Studi Pendidikan Guru Sekolah Dasar, STKIP Suar Bangli, Bangli, Bali, Indonesia \\ Corresponding author: I Nengah Sueca \\ E-mail: su3ca.nngah@gmail.com
}

\section{Diterima 12 November 2020, Direvisi 16 November 2020, Disetujui 16 November 2020}

\begin{abstract}
ABSTRAK
Pembelajaran di rumah tidak efektif sehingga berdampak pada rendahnya motivasi anak, termasuk kegiatan literasi dasar. Untuk mengatasi hal itu dilakukan pembinaan dan bimbingan kegiatan literasi dasar dalam pembelajaran di rumah selama pandemi Covid-19 untuk meningkatkan motivasi dan membantu kesulitan belajar siswa dalam belajar di rumah. Selain itu kegiatan pembinaan dan pembimbingan ini dapat membantu orang tua dalam melakukan pembinaan belajar di rumah yang terarah dan terstruktur. Adapun metode pelaksanaan dari kegiatan pengabdian ini, yaitu (1) Identifikasi masalah tentang permasalahan siswa; (2) melakukan analisis kebutuhan untuk mengatasi permasalahan yang terjadi saat pembelajaran di rumah selama pandemi Covid-19; (3) merancang pembinaan dan pendampingan kepada siswa dan orang tua siswa; (4) melaksankan pembimbingan terstruktur dan pembuatan bahan ajar permainan bahasa dalam kegiatan literasi dasar; (5) monitoring dan evaluasi kegiatan; (6) laporan dan tindaklanjut keberhasilan program. Pembinaan dan bimbingan kegiatan literasi dasar dalam pembelajaran di rumah selama pandemi covid-19 pada anak-anak rumahan di Banjar Dinas Temukus dapat meningkatkan motivasi dan membantu kesulitan belajar di rumah bagi anak-anak kelas rendah di Banjar Dinas Temukus. Hal tersebut terlihat dari semangat, antusias, dan keseriusan anak-anak yang ada dilingkungan rumah Banjar Dinas Temukus dalam kegiatan belajar di rumah.
\end{abstract}

Kata kunci: literasi dasar; pembelajaran di rumah; pandemi covid-19

\begin{abstract}
Home learning is ineffective, resulting in low children's motivation, including basic literacy activities. To overcome this, basic literacy coaching activities in learning at home were carried out during the Covid19 pandemic to increase motivation and help students' learning difficulties in learning at home. In addition, this coaching and mentoring activity can help parents in providing directed and structured coaching at home. The implementation methods of this service activity, namely (1) Identification of problems about student problems; (2) conduct a needs analysis to address problems that occurred during learning at home during the Covid-19 pandemic; (3) designing guidance and assistance to students and parents of students; (4) carry out structured guidance and manufacture of language game teaching materials in basic literacy activities; (5) monitoring and evaluation of activities; (6) reports and follow-up on program success. Coaching and guidance for basic literacy activities in learning at home during the Covid-19 pandemic for home children in the Banjar Dinas Temukus can increase motivation and help with learning difficulties at home for low-grade children in the Banjar Dinas Temukus. This can be seen from the passion, enthusiasm and seriousness of the children in the Banjar Dinas Temukus house in learning basic literacy activities at home.
\end{abstract}

Keywords: basic literacy; learning at home; the covid-19 pandemic

\section{PENDAHULUAN}

Banjar Dinas Temukus terletak di Desa Besakih, Kecamatan Rendang, Kabupaten Karangasem, yang terdiri atas tiga desa adat, yakni Desa Adat Temukus, Desa Adat Tukad Belah, dan Desa Adat Tarib. Secara geografis, Temukus terletak pada ketinggian antara 950-
$1100 \mathrm{~m}$ dari permukaan laut dengan curah hujan rata-rata 2000-3000 mm/tahun. Dikutip dari RPJM Desa Besakih tahun 2015, adapun luas wilayah Temukus adalah $361 \mathrm{Ha}$ dengan Jumlah penduduk 839 jiwa. Saat ini ada 100 lebih Siswa SD di Banjar Dinas Temukus, yang bersekolah di SD Negeri 5 melakukan 
pembelajaran di rumah, termasuk siswa kelas rendah (kelas I dan II).

Semenjak pandemi Corona Virus Disease (Covid-19), proses pembelajaran untuk dilaksanakan di rumah. Hal itu sesuai Surat Edaran Menteri Pendidikan dan Kebudayaan Nomor 4 Tahun 2020 tentang Pelaksanaan Pendidikan dalam Masa Darurat Covid-19. Begitu juga dengan siswa SD yang ada di Banjar Dinas Temukus yang juga melaksankan pembelajaran di rumah. Namun, pembelajaran dengan sistem ini kurang sesuai dengan perkembangan anak, khususnya pada anak kelas rendah.

Hasil observasi terhadap pembelajaran di rumah pada jenjang kelas rendah di Banjar Dinas Temukus diperoleh data bahwa (1) anakanak rumahan Banjar Dinas Temukus jarang melakukan kegiatan pembelajaran menggunakan daring ataupun media TV, (2) siswa kelas rendah tidak punya bahan pembelajaran di rumah, (3) kurang tersedianya fasilitas dan media pembelajaran di rumah, (4) orang tua jarang melakukan pendampingan belajar di rumah, (5) orang tua kurang percaya diri mengajar anaknya di rumah, (6) orang tua sibuk bekerja di ladang. Hal itu mengakibatkan pembelajaran di rumah tidak efektif sehingga berdampak pada rendahnya motivasi dan kemampuan siswa dalam memahami materi pelajaran, termasuk kegiatan literasi dasar pada siswa kelas rendah.

Terkait hal itu, materi pelajaran yang muncul pada jenjang SD kelas rendah adalah belajar membaca, menulis, dan berhitung. Materi ini wajib muncul sebagai pondasi awal dalam penanaman keilmuan yang paling dasar agar pengetahuan siswa dapat meningkat ke jenjang yang lebih tinggi. Penjabaran materi tersebut dapat dimulai dari pengenalan objek huruf dan angka sampai pada taraf merangkai beberapa huruf menjadi kata, kata menjadi kalimat, dan seterusnya. Pada sisi lain juga dimulai dengan mengenalkan bentuk huruf sampai ke operasi hitungan dari yang mudah ke tahap yang paling sulit.

Pada situasi pandemi Corona Virus Disease (Covid-19) ini, orang tua dituntut menjadi guru. Orang tua harus mampu memberikan bimbingan kepada anaknya pada saat belajar di rumah. Namun, kenyataannya banyak orang tua yang tidak siap mendampingi dan membimbing anaknya belajar di rumah. Hal tersebut dikarenakan kurangnya pengetahuan dan pengalaman orang tua dalam hal mengajar, tidak tahu apa yang harus diajarkan, bahkan tidak percaya diri dalam mengajar. Oleh karena itu, banyak orang tua yang kewalahan mengajar anaknya di rumah. Bahkan untuk mengajarkan literasi dasar, seperti membaca, menulis, dan menghitung.

Berbicara masalah literasi (khususnya literasi dasar) dalam pembelajaran di rumah di Banjar Dinas Temukus ada beberapa masalah yang dihadapi oleh anak-anak maupun orang tua. Hasil wawancara dengan I Nyoman Berata (orang tua siswa) diperoleh informasi bahwa anaknya, I Ketut Ardi Budiasa jarang ditemani belajar membaca di rumah karena keterbatasan waktu dan media ataupun bahan pembelajaran. Selain itu beliau mengatahan tidak tahu cara mengajar. Di sisi lain, I Wayan Sudiana, orang tua dari siswa I Made Diana Putra dan I Komang Surya Adi Putra juga mengatakan hal yang senada bahawa jarang punya waktu mengajari anakanya membaca di rumah. Selain itu, beliau tidak punya bahan yang harus diajarkan kepada anaknya.

Hasil observasi dilapangan juga menunjukkan masalah yang senada, ada beberapa masalah yang dialami anak-anak rumahan Banjar Dinas Temukus dalam kegiatan literasi dasar (belajar di rumah), yakni (1) anak-anak rumahan Banjar Dinas Temukus (kelas rendah, kelas I dan 2 SD) belum mampu mengeja huruf dengan baik, (2) anak-anak tersebut hafal abjad, tetapi tidak bisa mengeja kata, (3) anak tersebut tidak punya bahan pembelajaran di rumah, (4) anak-anak tersebut tidak memiliki fasilitas dan media pembelajaran di rumah, (5) orang tua jarang melakukan pendampingan belajar di rumah, (6) orang tua kurang percaya diri mengajar anaknya di rumah, (7) orang tua sibuk bekerja di ladang.

Berdasarkan permasalahan tersebut, solusi yang tepat ditawarkan adalah Pembinaan dan Bimbingan Kegiatan Literasi Dasar dalam Pembelajaran di Rumah selama Pandemi Covid-19 pada Anak-Anak Rumahan di Banjar Dinas Temukus. Adapun solusi tersebut dapat diparkan seperti berikut.

1. Pembinaan dilakukan terhadap siswa dan orang tua siswa Banjar Dinas Temukus dalam melaksnakan pembelajaran di rumah pada masa pandemi covid-19. Hal itu dilaksanakan sebagai upaya membantu anak-anak yang mengalami kesulitan belajar di rumah pada masa pandemi covid19 serta membantu orang tua dalam melakukan pembinaan dan pendampingan terhadap anak mereka saat belajar di rumah.

2. Bimbingan Kegiatan Literasi Dasar dilakukan pada siswa kelas rendah dengan memberikan bahan ajar berupa permainan bahasa untuk memudahkan anak-anak mengeja kata dan kalimat yang lebih kompleks. Pembinaan dilakukan secara terstruktur untuk membantu siswa belajar 
literasi dasar, seperti mengeja kata dan kalimat. Mulyadi (2010) menyatakan bahwa bimbingan adalah bantuan yang diberikan oleh seseorang yang memiliki pribadi yang baik dan pendidikan yang memadai, kepada seseorang individu dari setiap usia untuk menolongnya mengembangkan kegiatankegiatan hidupnya sendiri. Lebih jauh lagi menurut Sukardi (2002), pelayanan bimbingan belajar adalah berupa pelayanan bimbingan yang membantu siswa untuk dapat mengembangkan diri baik itu dari segi sikap dan kebiasaan belajar yang baik, materi belajar yang cocok dengan kecepatan dan kesulitan belajarnya, serta berbagai aspek tujuan dan kegiatan belajar lainnya, sesuai dengan perkembangan IPTEKS. Selain itu sesuai dengan hasil pengabdian masyarakat yang dilaksanakan oleh Darmayanti, dkk (2018) bimbingan belajar dapat mengatasi kesulitan belajar siswa. Oleh karena itulah, bimbingan Kegiatan Literasi Dasar dapat mengatasi permasalahan siswa dalam belajar di rumah saat pandemic covid-19.

Berdasarkan paparan di atas, maka penulis melaksanakan pengabdian Pembinaan dan Bimbingan Kegiatan Literasi Dasar dalam Pembelajaran di Rumah selama Pandemi Covid-19 pada Anak-Anak Rumahan di Banjar Dinas Temukus. Kegiatan tersebut dilakukan untuk mengatasi kesulitan belajar di rumah pada masa pandemi Covid-19 sehingga minat siswa belajar menjadi lebih baik.

\section{METODE}

Kegiatan pengabdian ini dilaksanakan di Banjar Dinas Temukus Karangasem dengan peserta anak-anak SD di Banjar Dinas Temukus yang berjumlah 10 orang Siswa. Pelaksanaan pengabdian ini memerlukan integrasi terpadu beberapa pihak, seperti penulis, orang tua, dan siswa dan tim pengabdian. Pengabdian ini dilaksanakan melalui metode PALS (participatory action learning system), yang dikembangkan oleh Linda Mayoux tahun 2000 (Chambers, 2007). PALS adalah salah satu metode pemberdayaan yang memiliki prinsip-prinsip: (1) $A$ defined methodology and systemic learning process, yaitu proses pembelajaran yang metodik, komulatif partisipatif, dan sistematik, (2) multiple perspectives, yaitu dalam pemberdayaan diutamakan pada pencapaian keragaman dan aksi-aksi yang beragam, (3) group learning processes, yaitu pemecahan kompleksitas masalah dunia nyata dengan proses rekognisi melalui inkuiri kelompok dan interaksi, (4) context specific, yaitu pendekatan penanganan masalah secara kontekstual, (5) facilitating experts and stakeholders, yaitu pemanfaat pakar dan partisipasi masyarakat dalam aksi perbaikan kondisi masyarakat, (6) leading to sustained action, yaitu penguatan kapasitas personal dan lembaga masyarakat dalam mengawal program aksi secara berkelanjutan. Metode PALS ini dapat digambarkan dalam bentuk bagan seperti yang ditunjukkan oleh Gambar 1 berikut.

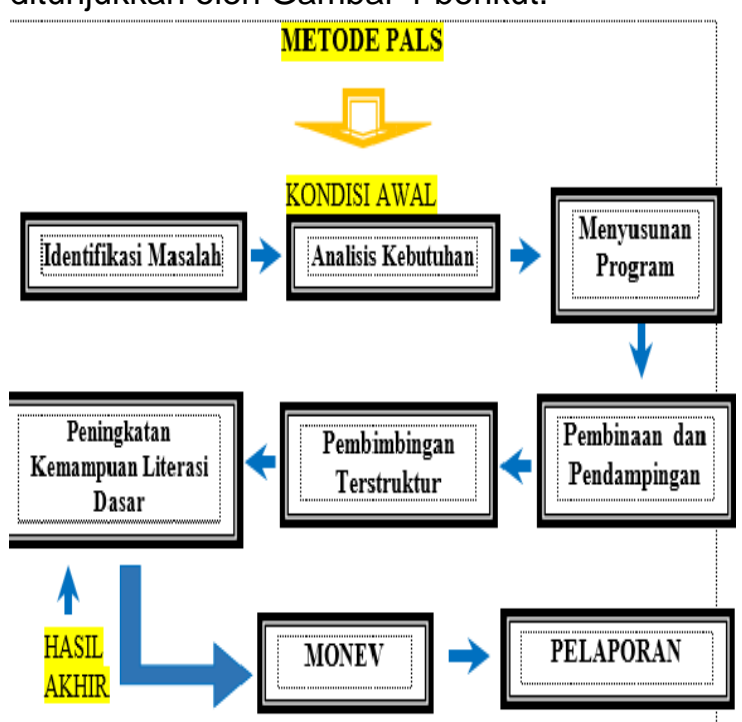

Gambar 1. Bagan Metode PALS

Metode pelaksanaan ini dapat dijabarkan sebagai berikut. (1) Identifikasi masalah tentang permasalahan siswa; (2) melakukan analisis kebutuhan untuk mengatasi permasalahan yang terjadi saat pembelajaran di rumah selama pandemi Covid-19; (3) merancang pembinaan dan pendampingan kepada siswa dan orang tua siswa; (4) melaksankan pembimbingan terstruktur dan pembuatan bahan ajar permainan bahasa dalam kegiatan literasi dasar; (5) monitoring dan evaluasi kegiatan; (6) laporan dan tindaklanjut keberhasilan program.

Pada tahap pelaksanaan program dilakukan (1) koordinasi dan pembekalan tim kerja pelaksana program sesuai peruntukan mengatasi masalah pengabdian. (2) Melaksanakan evaluasi diri dan penyusunan rencana program strategis sesuai dengan metode participatory action learning system (PALS). (3) Perancangan Program pembinaan dan pembimbingan kegiatan literasi dasar (4) Pelaksanaan aktivitas-aktivitas inisiasi program pengabdian, meliputi (a) pembinaan, (b) pendampingan, (c), pembimbingan terstruktur pada siswa.

\section{HASIL DAN PEMBAHASAN}

Pembinaan dan Bimbingan Kegiatan Literasi Dasar dalam Pembelajaran di Rumah selama Pandemi Covid-19 pada Anak-Anak 
Banjar Dinas Temukus dilaksankan dua kali seminggu, yakni hari Rabu dan Jumat. Kegiatan diawali dengan pengenalan kembali kegiatan baca tulis terhadap Anak-Anak Rumahan di Banjar Dinas Temukus. Pembinaan Kegiatan Literasi Dasar tahap I diawali dengan pengenalan Abjad dan pengenalan kegiatan membaca permulaan kepada siswa kelas rendah yang mulai melupakan kegiatan baca tulis (Gambar 2). Setelah itu dilakukan pendampingan terstuktur pada siswa tersebut.

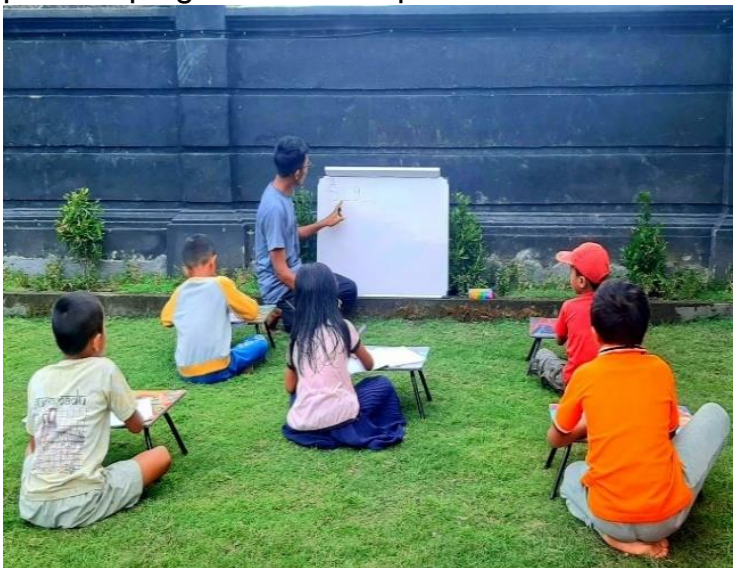

Gambar 2. Pembinaan Kegiatan Pengenalan Abjad (Literasi Dasar) pada Siswa Kelas Rendah (Kelas I)

Pada pertemuan berikutnya diberikan bimbingan terstruktur dengan pemberian materi berupa permainan kata untuk memudahkan siswa mengingat huruf, mengeja kata, dan menyusun kalimat. Hal itu dilakukan untuk meningkatkan kemampuan literasi dasar siswa kelas I anak-anak Rumahan Banjar Dinas Temukus. Kegiatan tersebut dapat memotivasi siswa dalam belajar membaca. Berikut disajikan (Gambar 3) yang menunjukkan kegiatan menyusun kalimat dari kata acak.

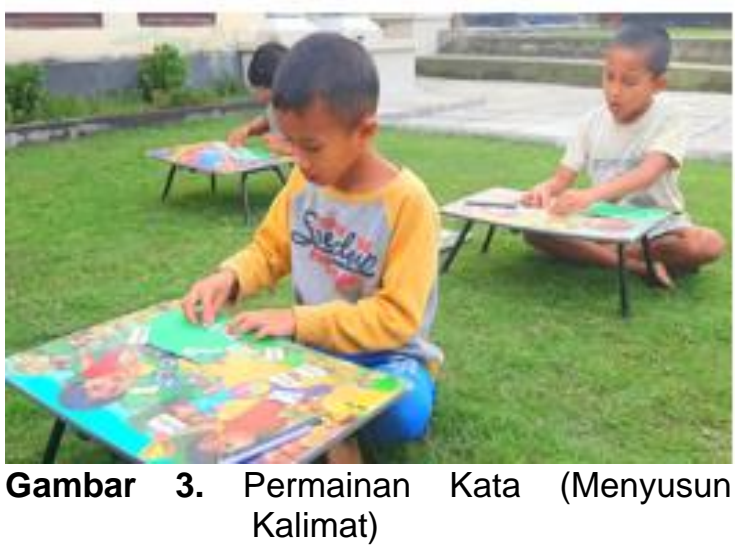

Pembimbingan kegiatan literasi dasar (baca dan tulis) pada pertemuan berikutnya dilakukan dengan pemberian permainan bahasa menyusun kata, menyusun kalimat , menjodohkan kata dengan gambar, dan permainan bahasa lainnya. Kegiatan yang dilakukan bertujuan untuk meningkatkan motivasi belajar literasi dasar pada siswa kelas rendah yang mengalami kesulitan belajar saat pandemic Covid-19. Kegiatan ini dapat merangsang kemapuan liteasi dasar siswa kelas I anak-anak rumahan Banjar Dinas Temukus. Berikut disajikan (Gambar 4) yang menunjukkan pembimbingan kegiatan literasi dasar.

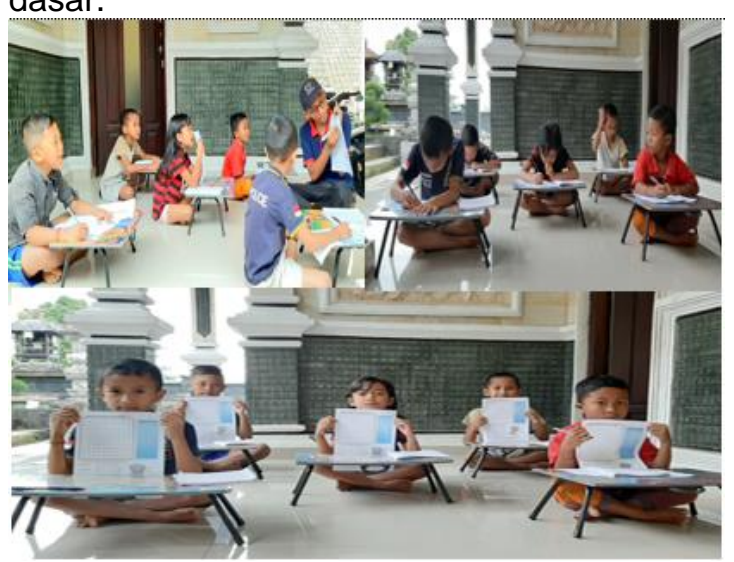

Gambar 4. Pembimbingan Kegiatan Literasi Dasar dengan Permainan Bahasa

Hasil bimbingan terstruktur kegiatan literasi dasar dengan pemberian permainan bahasa dapat mengatasi kesulitas siswa belajar di rumah pada masa pandemi Covid-19. Hal tersebut terlihat dari antusias siswa dalam belajar literasi dasar. Selain itu kemampuan siswa dalam baca tulis permulaan (literasi dasar) juga mengalami peningkatan sehingga permasalahan belajar di rumah bagi siswasiswa Rumahan banjar Dinas temukus dapat teratasi. Berdasarkan hal itu kegiatan pembinaan dan bimbingan kegiatan literasi dasar dalam pembelajaran di rumah selama pandemi covid-19 pada anak-anak rumahan di Banjar Dinas Temukus berhasil dan bermanfaat dalam meningkatkan motivasi belajar Literasi Dasar anak-anak rumahan di Banjar Dinas Temukus.

Keberhasilan dan kebermanfaatan pembinaan dan bimbingan dalam kegiatan literasi dasar dalam pembelajaran di rumah selama pandemi covid-19 pada anak-anak rumahan di Banjar Dinas Temukus dapat membantu anak-anak yang mengalami kesulitan belajar di rumah. Selain itu kegiatan ini juga dapat membantu orang tua dalam melakukan pembinaan belajar di rumah yang terarah dan terstruktur. Hal tersebut terlihat dari semangat, antusias, dan keseriusan anak-anak yang ada dilingkungan rumah Banjar Dinas Temukus dalam kegiatan belajar di rumah. Hal itu dapat dilihat dari keceriaan dan keantusiasan anak-anak dalam kegiatan literasi dasar yang dilakukan. Anak-anak aktif dalam belajar dan menyusun kata maupun 
kalimat dari bahan materi permaianan bahasa yang diberikan.

Selain itu, pada kegiatan ini anak-anak sudah bisa menjawab pertanyaan berupa menyelesaikan permainan bahasa yang diberikan ke dalam bentuk kalimat singkat. Siswa juga sudah mampu membaca kalimat yang disusun dari permainan bahasa yang diberikan. Hal tersebut menandakan bahwa anak-anak sudah paham terhadap materi yang diajarkan sehingga kesulitan-kesulitan yang dialami anak dalam kegiatan literasi dasar di rumah pada masa pandemi Covid-19 ini bisa teratasi. Dengan demikian kegiatan pembinaan dan bimbingan literasi dasar bermanfaat dengan baik untuk siswa belajar di rumah.

\section{SIMPULAN DAN SARAN}

Berdasarkan hasil dan pembahasan, simpulan pengabdian ini adalah sebagai berikut. Pembinaan dan bimbingan kegiatan literasi dasar dalam pembelajaran di rumah selama pandemi covid-19 pada anak-anak rumahan di Banjar Dinas Temukus dapat meningkatkan motivasi dan membantu kesulitan belajar di rumah bagi anak-anak kelas rendah di Banjar Dinas Temukus. Selain itu kegiatan ini juga dapat membantu orang tua dalam melakukan pembinaan belajar di rumah yang terarah dan terstruktur. Hal tersebut terlihat dari semangat, antusias, dan keseriusan anak-anak yang ada dilingkungan rumah Banjar Dinas Temukus dalam kegiatan belajar di rumah. Dengan demikian kegiatan pembinaan dan bimbingan literasi dasar sangat bermanfaat bagi anakanak rumahan Banjar Dinas Temukus dalam kegiatan belajar literasi dasar di rumah.

Adapun saran yang dapat diajukan adalah hendaknya perlu adanya pebinnaan pembimbingan, dan pendampingan untuk anakanak kelas rendah dalam belajar di rumah sebagai upaya mengatasi kesulitan belajar literasi dasar pada masa pandemi Covid-19.

\section{DAFTAR RUJUKAN}

Darmayanti, N. W. S., \& Zulkarnain, Z. (2018). PEMBERIAN PENGAYAAN MATERI PELAJARAN FISIKA UNTUK SISWA MELALUI KEGIATAN BIMBINGAN BELAJAR DI LUAR JAM SEKOLAH DI DESA GONTORAN, KECAMATAN LINGSAR, LOMBOK BARAT. SELAPARANG Jurnal Pengabdian Masyarakat Berkemajuan. https://doi.org/10.31764/jpmb.v1i2.454

Peraturan Menteri Pendidikan dan Kebudayaan Nomor 23 Tahun 2015 Tentang Program Gerakan Literasi Sekolah., (2015).

Mulyadi. (2010). Diagnosis Kesulitan Belajar. Nuha Litera.
Sagala, S. (2009). Konsep Dan Makna Pembelajaran. Alfabeta.

Šimková, E. (2007). Strategic approaches to rural tourism and sustainable development of rural areas. Agricultural Economics. https://doi.org/10.17221/979agricecon

Sukadi. (2009). Belajar dan Pembelajaran Bermuatan Konsep-konsep Kearifan Lokal. Undiksha.

Sukardi, K, D. (2002). Pengantar Pelaksanaan Program Bimbingan dan Konseling di Sekolah. Rineka Cipta. 